\section{Anderson Carlos Marafon ${ }^{1 *}$ \\ Lauricio Endres ${ }^{2}$}

${ }^{1}$ Empresa Brasileira de Pesquisa

Agropecuária - EMBRAPA, Embrapa Tabuleiros Costeiros, Av. Beira Mar, 3250, Jardins, 49025040, Aracaju, SE, Brasil

${ }^{2}$ Universidade Federal de Alagoas - UFAL, Centro de Ciências Agrárias, Reitoria, BR 104 - Norte, Cidade Universitária, 57072-970, Maceió, AL, Brasil

\section{Corresponding Author:}

*E-mail: anderson.marafon@embrapa.br

\section{KEYWORDS}

Silicates

Plant nutrition

Soil acidity

Environmental stress

\section{PALAVRAS-CHAVE}

Silicatos

Nutrição vegetal

Acidez do solo

Estresse ambiental

\title{
Silicon: fertilization and nutrition in higher plants
}

\author{
Silício: adubação e nutrição em plantas superiores
}

ABSTRACT: In this study, we aimed to provide information about the use of silicates in plant cultivation. Although silicon $(\mathrm{Si})$ is one of the most abundant elements found in most soils in substantial quantities, various classes of soils, mainly the sandy ones, present low amounts of available $\mathrm{Si}$ in their upper horizons. In these soils, some plants such as sugarcane and rice, which have keen ability to accumulate $\mathrm{Si}$ in their tissues, can respond favorably to silicon fertilization. Silicates behave similarly to calcium and magnesium carbonates in soil, promoting chemical reactions similar to those induced by limestone, including $\mathrm{pH}$ increase, precipitation of toxic aluminum $\left(\mathrm{Al}^{3+}\right)$ and manganese $\left(\mathrm{Mn}^{2+}\right)$, increase of exchangeable calcium and magnesium and base saturation levels, and reduction of $\mathrm{Al}^{3+}$ saturation, with the additional benefit of increasing Si levels in soils. Si benefits to plants are related mainly with increasing their resistance to attacks by insect pests, nematodes and diseases, and with reducing their transpiration rate, which provides further tolerance to water stress during periods of low soil moisture.

RESUMO: O objetivo deste trabalho foi fornecer informações sobre o uso de silicatos no cultivo de plantas. Apesar de o silício (Si) ser um dos elementos mais abundantes e estar presente na maioria dos solos em quantidades consideráveis, várias classes de solos, principalmente os arenosos, são pobres em Si nos horizontes superiores. Nesses solos, plantas como a cana-de-açúcar e o arroz, que têm grande capacidade de acumular Si em seus tecidos, podem responder favoravelmente à adubação silicatada. Os silicatos têm, no solo, comportamento similar aos carbonatos de cálcio e de magnésio, promovendo reações químicas semelhantes às provocadas pelo calcário, tais como: aumento do $\mathrm{pH}$, precipitação do alumínio $\left(\mathrm{Al}^{3+}\right)$ e do manganês $\left(\mathrm{Mn}^{2+}\right)$ tóxicos, aumento dos teores de cálcio e magnésio trocáveis, e da saturação de bases, e redução na saturação por $\mathrm{Al}^{3+}$, além do benefício adicional de aumentar os teores de Si no solo. Os efeitos benéficos do Si às plantas estão relacionados, principalmente, com o aumento da resistência ao ataque de insetos-praga, nematoides e doenças, e com a redução na taxa de transpiração, proporcionando maior tolerância à falta de água em períodos de escassez. 


\section{Introduction}

Silicon ( $\mathrm{Si}$ ) is the second most abundant element on the Earth, which is composed of $27.7 \% \mathrm{Si}$, second only to oxygen. In nature, $\mathrm{Si}$ only occurs in combination with other elements. The element occurs in two forms: silica or the oxides of silicon, which exist in crystalline or amorphous forms. It mainly occurs as an inert mineral of sands, quartz ( $\mathrm{SiO}_{2}$ pure), kaolinite, mica, feldspar and other clay minerals (for example, aluminum, magnesium, calcium, sodium, potassium or iron, forming silicates. Silicon, as silicic acid (0.1-0.6 mM) occurs as one of the main constituents of soil solution and it can be regarded as a plant nutrient (EPSTEIN, 2009).

$\mathrm{Si}$ has a key role in plant-environment relationships because it can improve plants' abilities to withstand edaphoclimatic and/or biological adversities by acting as a "natural anti-stress" mechanism that enables higher yields and a better-quality end product. Silicon plays a large number of diverse roles in plants, and does so primarily when the plants are under stressful conditions, whereas under benign conditions its role is often minimal or even nonexistent (EPSTEIN, 2009; MA, 2004).

Silicates most often benefit plants grown in $\mathrm{Si}$-poor soils and during adverse years, including prolonged periods of drought, frost, high incidence of pests and/or diseases. Under such conditions, plants with a good supply of Si tolerate a lack of water for a longer period because they more efficiently use the absorbed water and lose it at a lower speed than plants with a low Si level. Si increases crop productivity and improves technological quality, while the lack of this element can reduce the plants' biological ability to withstand adverse environmental conditions (RAFI; EPSTEIN; FALK, 1997).

In this study, we aimed to provide information about the use of silicates in plant cultivation.

\section{Silicon Reactions in the Soil}

In soils, available $\mathrm{Si}$ is found in the soil solution as silicic or monosilicic acid $\left(\mathrm{H}_{4} \mathrm{SiO}_{4}\right)$, mainly in the non-dissociated form ( $\left.\mathrm{pK}_{1}=9.6\right)$, which is easily absorbed by plants. This $\mathrm{Si}$ originates in weathering processes of primary minerals and, particularly, the secondary minerals, including clay silicates. In general, solutions of soils show liquid-phase Si levels varying between 2.8 and $16.8 \mathrm{mg} \mathrm{dm}^{-3}$, and the dynamic balance of the element in the soil depends on the pH (EPSTEIN, 1999).

The main sources of $\mathrm{Si}$ in soil solutions are the decomposition of plant residues, dissociation of polymeric $\mathrm{H}_{4} \mathrm{SiO}_{4}$, release of $\mathrm{Si}$ from $\mathrm{Fe}$ and $\mathrm{Al}$ oxides and hydroxides, dissolution of non-crystalline and crystalline minerals and addition of $\mathrm{Si}$ fertilizers and irrigation water (KORNDÖRFER; PEREIRA; CAMARGO, 2004). Drainage of $\mathrm{H}_{4} \mathrm{SiO}_{4}$ into the soil solution typically results in precipitation and/or polymerization, leaching, adsorption in oxides and hydroxides of $\mathrm{Fe}$ and $\mathrm{Al}$ and the actual absorption by the plants (LIMA FILHO; LIMA; TSAI, 1999).

Si fertilizers are mostly neutral or slightly alkaline. According to Savant et al. (1999), the neutralizing effect promoted by silicates on soil acidity occurs through the following reactions of $\mathrm{SiO}_{3}^{-2}$ anions with $\mathrm{H}^{+}$protons in the soil solution:

$$
\begin{gathered}
\mathrm{CaSiO}_{3}+\mathrm{H}_{2} \mathrm{O} \leftrightarrow \mathrm{Ca}^{2+}+\mathrm{SiO}_{3}^{-2}+\mathrm{H}_{2} \mathrm{O} \\
\mathrm{SiO}_{3}^{-2}+2 \mathrm{H}^{-} \leftrightarrow \mathrm{H}_{2} \mathrm{SiO}_{3} \\
\mathrm{H}_{2} \mathrm{SiO}_{3}+\mathrm{H}_{2} \mathrm{O} \leftrightarrow \mathrm{H}_{4} \mathrm{SiO}_{4}
\end{gathered}
$$

Despite Si being one of the most abundant elements and found in most soils in substantial quantities, various classes of soils, mainly sandy ones, are low in $\mathrm{Si}$ in the upper horizons (MARSCHNER, 1995). Clay soils show higher concentrations of phyllosilicates (minerals that release $\mathrm{Si}$ and $\mathrm{Al}^{3+}$ ) and a higher concentration of $\mathrm{Si}$ than sandy soils. Although the sand fraction consists mostly of quartz $\left(\mathrm{SiO}_{2}\right)$, the chemical decomposition of this mineral is complex, which makes sandy soils more responsive than clay soils to silicate application (DEMATTÊ et al., 2011). Tropical and subtropical soils undergoing intensive management and monoculture that are subject to weathering and leaching usually have high levels of Al, low base saturation, high phosphorus-fixation capacity, high acidity levels (MATICHENKOV; CALVERT, 2002) and low levels of available $\mathrm{Si}$, due to the process of desilication (EPSTEIN, 1999).

\section{Silicon Uptake by Plants}

Increases in $\mathrm{Si}$ availability in the soil are usually accompanied by increased Si content in the plant, which may result in increased growth and productivity in several grasses, especially rice, sugarcane, sorghum, millet, Brachiaria, oat, wheat, and corn, and in some non-grass species such as soybean, bean, tomato, strawberry, and cucumber (MA; YAMAJI, 2008).

$\mathrm{Si}$ is absorbed by plant roots in its neutral form $\left(\mathrm{H}_{4} \mathrm{SiO}_{4}\right)$ through a passive process regulated by transpiration stream, which occurs via the xylem, along with water (mass flow) or by an active process, through transporters located in the plasma membrane of root cells (RODRIGUES et al., 2011). The absorbed Si accumulates in the plant's oldest tissues, mainly in the walls of epidermal cells, as polymerized monosilicic acid or amorphous silica $\left(\mathrm{SiO}_{2} \cdot \mathrm{nH}_{2} \mathrm{O}\right)$, which strengthens cell walls and increases the structural rigidity of tissues. Silica deposition may happen in the secondary cell wall during cellulose synthesis, similar to lignification. Long-distance $\mathrm{Si}$ transport is restricted to the xylem, with large quantities of $\mathrm{Si}$ deposited in the cell walls of these vessels. This $\mathrm{Si}$ deposition may prevent compression of the xylem when the transpiration rate is high (MITANI; MA, 2005), for example, in environments with high vapor pressure deficit.

$\mathrm{Si}$ is concentrated in supporting tissues the stems and leaves can still be found in small amounts in grains. In general, the average Si root levels are one-tenth of the concentration in the stems and leaves; however, in the case of soybeans, Si levels are higher in the roots than in the leaves. Silica is deposited mainly in the epidermis and in sheath cells of vascular bundles. It occurs in cell walls, cell lumens, in inter-cellular matrix, and in a layer under the wax cuticle. The silica in silica cells is deposited after the protoplast is degraded, and silica is deposited to higher degree in wounded cells, and in older cells (BAUER; ELBAUM; WEISS, 2011). Frequently, the accumulation of $\mathrm{Si}$ occurs in regions of maximum transpiration, such as: leaf epidermis near the stomatal guard cells, trichomes and thorns, which mitigates the effects of biotic and abiotic stresses (DAYANANDAM; KAUFMAN; FRAKIN, 1983). 
There is great variability in the genetic ability of a cultivar to accumulate Si. Plants, in general, have Si levels ranging from 0.1 to $10 \%$ of their total dry matter. Those with leaf levels above $1 \%$ of their dry matter are considered accumulators, and those with levels below $0.5 \%$ are considered non-accumulators. Plants differ markedly in their ability to absorb $\mathrm{Si}$, and even different genotypes of the same species may have different $\mathrm{Si}$ concentrations in their tissues (MA; MIYAKE; TAKAHASHI, 2001).

The family Poaceae, which includes the rice and sugarcane crops, has a keen ability to accumulate $\mathrm{Si}$ in its tissues, where $\mathrm{Si}$ levels can match or even exceed those of primary macronutrients (EPSTEIN, 1999; RAFI; EPSTEIN; FALK, 1997). Sugarcane varieties show genetic variability regarding $\mathrm{Si}$ accumulation in their tissues, with a close relationship between Si levels in leaves and soil (DEREN; GLAZ; SNYDER, 1993). The levels may vary from very low in young leaves $(0.14 \%)$ to very high in old leaves (6.7\%) (KORNDÖRFER; DATNOFF, 1995).

The silicic acid $\left(\mathrm{H}_{4} \mathrm{SiO}_{4}\right)$ transporters known were first described in rice. This species has a high requirement for $\mathrm{Si}$. The known transporters comprise Lsi1, Lsi2 and Lsi6 transport proteins (abbreviation "Lsi", "low silicon") (MA et al., 2006). A search through grass databases of expressed sequence tags (derived from mRNA transcripts) revealed novel putative sequences of aquaporin-type Si channels of wheat, sorghum and maize. Ma and Yamaji (2008) also identified active Si transporters in rice, barley and maize. Two transporters (influx and efflux) located in root cells are involved in the absorption and transport of $\mathrm{Si}$, and another transporter that is located in the parenchyma cells of the leaves' xylem is responsible for Si efflux. Recently, different Si transporter genes have been identified in maize (Zea mays L.) and barley (Hordeum vulgare L.) (MITANI et al., 2009).

\section{Silicon Effects against the Environmental Stresses}

The potential benefits of Si nutrition in plants includes the enhancement of growth and yield, improvement of mechanical properties (stature, soil penetration by roots, exposure of leaves to light, resistance to lodging), reduction of transpiration and resistance to drought stress, resistance to salinity, resistance to metal toxicities, effects on enzyme activities and increased resistance to pathogens). Silicon benefits plants are by increasing their resistance to attack by insect pests, nematodes and diseases as well as by reducing their transpiration rate by controlling the stomatal opening and closing mechanism, which provides further tolerance to water shortages during periods of low soil moisture (KORNDÖRFER; DATNOFF, 1995; KORNDÖRFER; PEREIRA; CAMARGO, 2002).

The Si use also alleviates the effects of excessive heavy metals and salt stress, increases tolerance to heavy nitrogen fertilization and the mechanical strength of stems (and decreases susceptibility to lodging), improves plant architecture (with better light penetration in the canopy because of the more upright growth of leaves and reduced self-shading) (MA; TAKAHASHI, 2002; PRADO; FERNANDES, 2000) and protects leaves against damage caused by ultraviolet radiation (TISDALE; NELSON; BEATON, 1993).
The mechanisms of $\mathrm{Si}$-induced resistance of plants to pests and diseases result from its association with cell wall components, making them less accessible to degradation enzymes (DATNOFF; RODRIGUES; SEEBOLD, 2007). The cell wall rigidity and thickening caused by the deposition of silica in the epidermis act as mechanical resistance factors. $\mathrm{Si}$-induced plant protection is related to the accumulation and polymerization of $\mathrm{Si}$ in cells, which forms a physical barrier via cell wall hardening and hinders attack by pests and diseases (EPSTEIN, 1999).

Traditionally, silica is thought to improve the plant fitness mainly through the formation of structures that are much stiffer than non-mineralized cell walls. The physical features include structures such as thorns, spines, trichomes, raphides, rough, tough epidermal cells, and hard shells and pods. Many plants armour themselves with solid hydrated amorphous silica, or opal, incorporated in cell walls. Reinforcement of the cell wall by deposition of solid silica in them is one of the ways in which the protection against insect pests is effected by the plant species. Furthermore, it is also possible that silica fortification of the cell wall is tied with biosynthesis of phenolic compounds. The phenolic polymers may be deposited in the thickening cell wall, and eventually induce silicification in dying cells (LIANG et al., 2007).

The Si roles may be compared with those of the organic secondary metabolites. It is indeed likely that this 'quasiessential' element is instrumental in the generation of these defence metabolites. Thus, in analogy to organic secondary metabolites, silicon may be looked upon as an inorganic secondary nutrient. Seeing the manifold roles that silicon plays in the plant defence against adversities we must admit that we are still far from formulating a 'unified field theory' of silicon in agriculture (EPSTEIN, 2009).

\subsection{Silicon in the alleviation of abiotic stresses}

In water-deficit environments, $\mathrm{Si}$ accumulation in leaves causes the formation of a double layer of cuticle silica, which reduces the transpiration rate, decreasing the opening of stoma and limiting the loss of water in plants. This effect can be significant, especially for gramineae growing in regions where the dry season is long and severe (NOLLA et al., 2012; MA; MIYAKE; TAKAHASHI, 2001). The cultivation of sugarcane in traditional areas, for example, occasionally faces severe droughts that can drastically impair the productivity of sugarcane crops, despite the high tolerance of sugarcane to water stress, leading to wide variations in yield between crop years, especially in the Northeast region of Brazil (MADEIROS; VIEIRA; AQUINO, 2009). In this sense, some authors found that $\mathrm{Si}$ application increases resistance to drought and other biotic and abiotic stresses (GAO et al., 2004; MA, 2004). Si in leaves would fill the interfibrillar spaces and reduce the movement of water through the cell wall, which would conserve water by decreasing the transpiration rate (SAVANT et al., 1999).

Si fertilizer application can also alleviate the adverse effects of salt stress on plants by increasing cell membrane integrity and stability through its ability to stimulate the plants' antioxidant system. In salty conditions, the Si deposited in 
the cell walls of roots, leaves and stalks as silica gel reduces $\mathrm{Na}$ absorption and transport, alleviating the adverse effects of salt on plant growth (ZUCCARINI, 2008), as for example in the case of sugarcane cultivated under irrigation of arid and semiarid regions, which are frequently subjected to salt stress (ASHRAF et al., 2004).

In vascular plants, $\mathrm{Si}$ can reduce the adverse effect of abiotic stress caused by toxic or heavy metals. Si can reduce the toxicity of potentially toxic elements, such as Al, within the plant through the stimulation of the antioxidant system, metal ion chelation, immobilization of heavy metals during plant growth or compartmentalization of heavy metals in vacuoles, the cytoplasm or the cell wall (LIANG et al., 2007). $\mathrm{Si}$ is known to play a role, both in the soil and within plants, in decreasing the bioavailability of potentially toxic heavy metals. In plants, the alleviating effect of $\mathrm{Si}$ can be attributed to 1) metal retention in the roots and inhibition of translocation to the shoots; 2) reduction of plasma membrane lipid peroxidation (SHI et al., 2005); 3) accumulation of $\mathrm{SiO}_{2}$ in the root apoplasm and leaf surface, forming barriers to metal ion apoplastic and transpirational flows, respectively (LUX et al., 2002); 4) co-precipitation of Si-metal complexes in the cell wall and compartmentalization of metals with organic acids in the vacuoles and 5) formation of $\mathrm{Si}$ - polyphenol complexes in tissues (MAKSIMOVIC et al., 2007). In the case of manganese toxicity, which is responsible for necrotic and brown spots on leaves, the addition of Si can suppress the increase of phenolic compounds caused by the excess of this element, reducing or even preventing the onset of toxicity symptoms (ROGALLA; ROMHELD, 2002).

A model to explain the Si-mediated alleviation of $\mathrm{Al}$ phytotoxicity through the formation of aluminosilicates (AS) and hydroxyl-aluminosilicates (HAS) in the apoplast of plants was proposed by Cocker, Evans and Hodson (1998). The formation of AS and HAS would occur by both the direct interaction between $\mathrm{Si}$ and $\mathrm{Al}$ within the cell walls of apical cells and the Si-induced cell exudation of organic acids or $\mathrm{H}^{+}$. Worldwide, Al toxicity affects vast regions with acid soils. Si helps protect plants from the toxic effects of this element through the formation of inert HAS in the soil solution (EXLEY, 1998).

\subsection{Silicon in the alleviation of biotic stresses}

Polymerized silica is one of the hardest materials in the plant tissue. This is supported by the fact that plants attacked by herbivores tend to accumulate more silica in their leaves than non-attacked plants, and that higher silicification correlates with lower herbivory. Increased cell wall mechanical resistance is induced by an increased density of epidermal cells, which results from the deposition and polymerization of monosilicic acid below the cuticle. This process is triggered by $\mathrm{Si}$ accumulation in the leaf blade, forming a cellulose-silica double layer, which confers resistance to fungal diseases by preventing hyphal penetration (YOSHIDA; OHNISHI; KITAGISHI, 1962).

Si-induced attenuation of pest attacks can be 1) direct, by mandibular wear of chewing insects, or 2) indirect, by attracting natural enemies of pests (KVEDARAS et al. 2007;
KEEPING; KVEDARAS; BRUTON, 2009). Whereas the direct effects include reductions in the growth and reproduction of insects, the indirect effects are usually related to the reduction or delay of insect penetration in the plant tissues.

The use of silicates in sugarcane has shown positive results in the control of pests and diseases (RODRIGUES et al., 2011). Thus, Si can be significant for integrated pest and disease management, especially through plant resistance induction. It also contributes to the supply of nutrients and helps correct soil acidity (RODRIGUES et al., 2011). Attack by pests, especially the sugarcane borer (Diatraea saccharalis), leaf (Mahanarva posticata) and root (Mahanarva fimbriolata) spittlebugs and diseases, such as sugarcane brown rust (Puccinia melanocephala) (NAIDOO et al., 2009) and leaf sheath ringspot (Leptosphaeria sacchari), could be reduced in the cultivars that accumulate Si (KORNDÖRFER; PEREIRA; CAMARGO, 2002).

The African sugarcane borer (Eldana saccharina) is one of the most destructive sugarcane pests in South Africa. In an experiment conducted in that country with six commercial sugarcane varieties using two doses of calcium silicate (5 and $10 \mathrm{Mg} \mathrm{ha}^{-1}$ ), which were compared to controls (without $\mathrm{Si}$ ), plants were artificially infested with E. saccharina at 9.5 months after planting and collected 6 months later. Si treatments resulted in a significant increase in resistance to borer attack. Regarding of the attack site, the African sugarcane borer prefers to penetrate through sugarcane bud scales, where $\mathrm{Si}$ accumulation is proportionately less than in the internode and root areas (KEEPING; KVEDARAS; BRUTON, 2009). Silicate-induced $\mathrm{Si}$ accumulation in sugarcane leaves resulted in the partial control of the sugarcane borer (D. saccharalis) (CAMARGO et al., 2010). Stalk Si levels increased in proportion to the doses of silicate applied, and reductions of $20 \%$ in insect mass and $23 \%$ in the amount of stalks bored were found when $5,000 \mathrm{~kg} \mathrm{ha}^{-1}$ of $\mathrm{CaSiO}_{3}$ (equivalent of $396 \mathrm{~kg}$ of pure $\mathrm{Si}$ ) were applied (KEEPING; MEYER, 2002).

The silicate soil application can affected the development of the root spittlebug ( $M$. fimbriolata), decreasing male and female longevity in the laboratory and nymphal population under field conditions, improving raw material quality. The potassium silicate use in areas cultivated with sugarcane reduced the chances of $M$. fimbriolata populations reaching economically damaging levels. As the practice of burning sugarcane before harvest gradually ceases, as required by Brazilian law, populations of spittlebugs will likely increase, and the use of silicates may become a significant element in the sugarcane' pests integrated management (KORNDÖRFER; GRISOTO; VENDRAMIM, 2011).

Regarding tolerance to diseases, several studies in various monocotyledonous and dicotyledonous species have shown that supplying $\mathrm{Si}$, whether through soil, leaf or nutrient solution, significantly contributes to reducing the intensity of numerous diseases of economic significance (BÉLANGER et al., 1995). The most widely accepted mechanism of resistance to pests and diseases induced by $\mathrm{Si}$ application is mechanical. However, another hypothesis is that Si acts as a gene and signaling activator of the biosynthesis of defense compounds in a process known as systemic acquired resistance (SAR), 
in which phytoalexins, phenols and phenylpropanoids are synthesized (FAWE et al., 2001).

Significant decreases in sugarcane leaf diseases, including rust and brown spot, were verified upon application of $6.7 \mathrm{Mg} \mathrm{ha}^{-1}$ slag (RAID; ANDERSON; ULLOA, 1992). The first cytological evidence of the $\mathrm{Si}$-mediated increase in rice resistance to blast because of the accumulation of phenolic compounds was showed by Rodrigues et al. (2003). Therefore, Si could trigger natural defense mechanisms through the production of phenolic compounds, chitinases and peroxidases as well as lignin accumulation (GOMES et al., 2008), interfering in the growth and development of insect pests and/or phytopathogenic agents. Si can improve the host plant defense through a third trophic level, enhancing the attraction of natural enemies, with the consequent biological control by the induction of plant resistance, likely through different volatile compounds produced by insect-attacked plants (REYNOLDS; KEEPING; MEYER, 2009).

\section{Use of Silicon (Si) Fertilizers}

In Brazil, the material most often used as a soil acidity neutralizer is limestone. However, a possible solution to soil acidification is the surface application of other neutralizers, including calcium-magnesium silicates. Silicates behave like calcium and magnesium carbonates in soil, promoting similar chemical reactions to those induced by limestone, including increasing the $\mathrm{pH}$, precipitating toxic $\mathrm{Al}$ and $\mathrm{Mn}$, increasing the exchangeable $\mathrm{Ca}$ and $\mathrm{Mg}$ levels and saturation of bases and reducing the saturation of $\mathrm{Al}^{3+}$, with the additional benefit of increasing the Si levels in soils (EPSTEIN, 1999; SAVANT et al., 1999). Several authors (KORNDÖRFER; PEREIRA; NOLLA, 2004) demonstrated the similarity between slag and lime regarding their ability to neutralize acidity and increase soil base saturation and reported that slag reacts more slowly than lime in soil over successive crop cycles. In addition to supplying nutrients (calcium, magnesium and $\mathrm{Si}$ ) to the soil, another significant aspect of silicates' effects on soil properties regards their interaction with phosphorus and nitrogen-phosphorus-potassium (NPK) fertilization.

Fertilizers containing Si minerals can be categorized as simple (Table 1), mixed, complex, organomineral or acidityneutralizing mineral fertilizers. Among the materials used as a source of Si by plants are slag, wollastonite, byproducts of elemental phosphorous production, calcium, sodium, potassium and magnesium silicates (serpentinite), cement and fused phosphate (LIMA FILHO; LIMA; TSAI, 1999).

Silicates are applied to soil mainly as solids (powder or granulate) or liquids (via soil or leaves). Whereas silicates in powder form are incorporated into the entire area, granulates are applied in lines, along with NPK fertilizers, which facilitates the supply of Si near the root system and its absorption by the plant. By law, slag should show maximum levels of $20 \mathrm{mg} \mathrm{kg}^{-1}$ cadmium (Cd) and $1000 \mathrm{mg} \mathrm{kg}^{-1}$ lead $(\mathrm{Pb})$, in addition to the minimum guarantees required $(10 \%$ $\mathrm{Si}$ and $10 \% \mathrm{Ca})$.

In the process of choosing the silicate source, one must consider the relative power of total neutralization and the distance between the steelworks and the application site. Thus, analysis of the cost/benefit ratio will determine the feasibility of applying silicate in place of lime. The ideal features of a good silicate are a high concentration of available $\mathrm{Si}$, good physical properties, ease of mechanized application, readily available to plants, high amounts of $\mathrm{Ca}$ and $\mathrm{Mg}$, low concentration of heavy metals and low cost (PRADO; FERNANDES; NATALE, 2001).

The use of residues from steelworks has proven to be a viable alternative to soil acidity correction, especially slag, which is an iron and steel industry byproduct that is a cheap

Table 1. Simple fertilizers containing silicon $(\mathrm{Si})$.

\begin{tabular}{|c|c|c|c|c|}
\hline Fertilizer & $\begin{array}{l}\text { Minimum } \\
\text { guarantees }\end{array}$ & Features & Obtention & Observations \\
\hline Slag silicate & $\begin{array}{l}10 \% \mathrm{Si} \\
10 \% \mathrm{Ca}\end{array}$ & $\begin{array}{l}\text { Total } \mathrm{Si} \text { as silicate. } \\
\text { Total calcium. Granulometry: } \\
\text { powder. }\end{array}$ & $\begin{array}{l}\text { Slag treatment and grinding } \\
\text { (slag) obtained by the iron and } \\
\text { steel industry. }\end{array}$ & $\begin{array}{l}\text { Powder. Acidity neutralizer. } \\
\text { Can contain magnesium. }\end{array}$ \\
\hline Calcium silicate & $\begin{array}{l}20 \% \mathrm{Si} \\
29 \% \mathrm{Ca}\end{array}$ & Total Si as calcium Silicate. & $\begin{array}{l}\text { Slag treatment and grinding } \\
\left(>1000{ }^{\circ} \mathrm{C}\right) \text { of silicate } \\
\text { compounds. }\end{array}$ & $\begin{array}{l}\text { Powder, branny, thin branny } \\
\text { and grainy. It is also an acidity } \\
\text { neutralizer. }\end{array}$ \\
\hline $\begin{array}{l}\text { Calcium and } \\
\text { Magnesium } \\
\text { Silicate }\end{array}$ & $\begin{array}{l}10 \% \mathrm{Si} \\
7 \% \mathrm{Ca} \\
1 \% \mathrm{Mg}\end{array}$ & $\begin{array}{l}\text { Total Si as calcium Silicate. } \\
\text { Total magnesium. }\end{array}$ & $\begin{array}{l}\text { Slag treatment and grinding. } \\
\text { Grinding and thermal treatment } \\
\left(>1000^{\circ} \mathrm{C}\right) \text { of dolomite-silicate } \\
\text { compounds. }\end{array}$ & $\begin{array}{l}\text { Powder, branny, thin branny } \\
\text { and grainy. It is also an acidity } \\
\text { neutralizer. }\end{array}$ \\
\hline $\begin{array}{l}\text { Potassium } \\
\text { Silicate Solution }\end{array}$ & $\begin{array}{l}10 \% \mathrm{Si} \\
10 \% \mathrm{~K}_{2} 0\end{array}$ & $\begin{array}{l}\text { Water-soluble } \\
\text { Si and K }\end{array}$ & $\begin{array}{l}\text { Reaction of silicate minerals } \\
\text { with potassium hydroxide }\end{array}$ & \\
\hline $\begin{array}{l}\text { Fused } \\
\text { Magnesium } \\
\text { Potassium } \\
\text { Phosphate }\end{array}$ & $\begin{array}{l}12 \% \mathrm{P}_{2} \mathrm{O}_{5} 4 \% \\
\mathrm{~K}_{2} \mathrm{O} 16 \% \mathrm{Ca} 7 \% \\
\mathrm{Mg} 10 \% \mathrm{Si}\end{array}$ & $\begin{array}{l}\text { Citrate-soluble phosphorous } \\
\left(\mathrm{P}_{2} \mathrm{O}_{5}\right) \text { and potassium }\left(\mathrm{K}_{2} \mathrm{O}\right) \\
(2 \%) \text { in } 1: 100 \text { ratio. } \\
\mathrm{Ca}, \mathrm{Mg} \text { and } \mathrm{Si} \text { levels. } \\
\text { Granulometry: powder and thin } \\
\text { branny. }\end{array}$ & $\begin{array}{l}\text { After heat treatment at least } \\
1000{ }^{\circ} \mathrm{C} \text { (foundry) of natural } \\
\text { phosphate or concentrated } \\
\text { apatite with the addition of } \\
\text { magnesium, potassium and } \\
\text { silicon compounds. }\end{array}$ & It is also an acidity neutralizer. \\
\hline
\end{tabular}

Source: Brasil (2012). 
and abundant source of silicates because its main constituents are calcium and magnesium silicates (MALAVOLTA; PIMENTEL-GOMES; ALCARDE, 2002). Slag results from the reaction of lime with silica present in iron ore processed at high temperatures $\left(>1400{ }^{\circ} \mathrm{C}\right)$. Brazil is the sixth largest producer of pig iron, with an annual production of approximately 25 million tons, generating approximately 6.25 million tons of slag (PRADO; FERNANDES; NATALE, 2001).

Slag is rich in $\mathrm{Si}$ as well as $\mathrm{Ca}$ and $\mathrm{Mg}$ oxides, which makes it an excellent source of nutrients at low cost, and it acts as a soil acidity neutralizer because of its high $\mathrm{pH}$, especially in sandy and low-fertility soils (DATNOFF; SNYDER; KORNDÖRFER, 2001). Among the main problems of the agricultural use of slag is that the slag production sites are often distant from the application sites, increasing the product cost. The action of silicates is remarkably similar to that of limestone. The calcium silicate $\left(\mathrm{CaSiO}_{3}\right)$ is about 6.78 times more soluble than calcium carbonate $\left(\mathrm{CaCO}_{3}\right)$, which makes it more effective and with a faster action than that of limestone in neutralizing $\mathrm{pH}$, especially in semi-perennial crops, including sugarcane (ALCARDE, 1992).

\section{Silicate Effects on Sugarcane Productivity}

Much of the area cultivated with sugarcane in Brazil is located in regions with soil acidity problems resulting, in most cases, from the progressive soil acidification process that is common to tropical soils with a low availability of exchangeable bases (PRADO; FERNANDES, 2001a; FOY, 1992). In these regions, liming is required, which supplies calcium and magnesium; corrects the soil acidity; neutralizes toxic elements, including aluminum and manganese and increases nutrient availability.

Although it is not considered an essential nutrient, $\mathrm{Si}$ is the element most absorbed by sugarcane, followed by K, nitrogen (N), Ca and Mg (TISDALE; NELSON; BEATON, 1993). Several studies conducted in Brazil and abroad have reported beneficial effects of $\mathrm{Si}$ in areas of sugarcane cultivation. In these areas, where silicate was applied as an acidity neutralizer, there was a decrease in plant tipping and clumps being gouged out during mechanized harvest and an extension of the useful life of the sugarcane crop (DEMATTÊ et al., 2011).

Sugarcane cultivation has an enormous Si removal potential. Approximately $300 \mathrm{~kg} \mathrm{ha}^{-1} \mathrm{Si}$ are removed in a production of $100 \mathrm{Mg} \mathrm{ha}^{-1}$, and up to $500 \mathrm{~kg} \mathrm{ha}^{-1}$ are removed under high productivity. One research, for example, reported an export of $408 \mathrm{~kg} \mathrm{ha}^{-1} \mathrm{Si}$ for a sugarcane productivity of $74 \mathrm{Mg} \mathrm{ha}^{-1}$ (leaves + stalks). Linear increases in $\mathrm{Si}$ soil levels were verified as a function of slag doses applied to soil cultivated with sugarcane. In these work, one hundred and twenty days after the use of 100,200 and $400 \mathrm{~kg} \mathrm{ha}^{-1} \mathrm{Si}$, the total $\mathrm{Si}$ levels increased by 18, 56 and $72 \%$, respectively (SOUSA; KORNDÖRFER; WANGEN, 2010). Comparative effect of silicate and limestone in sugarcane production showed that $\mathrm{Si}$ accumulation resulted in increased productivity, which was caused by reduction of transpiration and improvement of plant architecture.
The elevate sugarcane productivity is associated with high $\mathrm{Si}$ concentrations in leaves (MATICHENKOV; CALVERT, 2002). When sugarcane leaf blades contain less than $1 \% \mathrm{Si}$, the plant may have reduced growth, low tillering, premature leaf senescence, budding failures and deficiency symptoms in leaves directly exposed to sun (ELAWAD; GASCHO; STREET, 1982). Si-deficiency symptoms in sugarcane leaves are characterized by small circular white spots (freckles) in older leaves, a symptom known as leaf freckling (ANDERSON; BOWEN, 1992; ORLANDO FILHO; MACEDO; TOKESHI, 1994). According to Korndörfer, Pereira and Nolla (2004), the average sugarcane-induced extraction of $\mathrm{Si}$ is $250 \mathrm{~kg} \mathrm{ha}^{-1}$, and the average $\mathrm{Si}$ levels found in tissues range from 0.33 to $0.5 \%$ in bagasse and from 0.7 to $1.9 \%$ in leaves.

The average accumulation of $350 \mathrm{~kg} \mathrm{ha}^{-1} \mathrm{Si}$ in sugarcane shoots were found for a stalk productivity of $110 \mathrm{Mg} \mathrm{ha}^{-1}$ (ARRUDA, 2009). This author found that the soil and leaf Si levels positively correlated with stalk productivity under field conditions. In areas with leaf Si levels of $22 \mathrm{~g} \mathrm{~kg}^{-1}$, the average stalk productivity was $160 \mathrm{Mg} \mathrm{ha}^{-1}$, whereas, in areas with leaf levels of $15 \mathrm{~g} \mathrm{~kg}^{-1}$, the productivity was $128 \mathrm{Mg} \mathrm{ha}^{-1}$.

The positive effect of slag on the increase in sugarcane yield has been attributed to its neutralizing effect in soils more than the Si nutrient effect (DEMATTÊ et al., 2011). assessing the response of sugarcane to slag application as an acidity neutralizer, found that productivity was positively influenced, reaching 100 and $75 \mathrm{Mg} \mathrm{ha}^{-1}$ above the cane plant $\left(89 \mathrm{Mg} \mathrm{ha}^{-1}\right)$ and ratoon crop (58 $\mathrm{Mg} \mathrm{ha}^{-1}$ ) controls, respectively (PRADO, 2000). The use of limestone and slag in sugarcane grown in pots cause similarly increased in the $\mathrm{Ca}$ and $\mathrm{Mg}$ in the soil (PRADO; FERNANDES, 2000).

The slag application linearly increased stalk production in the cane plant cycle, with a quadratic increase in plant height and a positive residual effect of the slag on the production of the ratoon crop (PRADO; FERNANDES; NATALE, 2003). In a study of different sources of silicate in sugarcane grown in Florida (USA), in which two were slags and one was cement, the materials were applied and incorporated at pre-planting and, regardless of their source, significantly increased the height and stalk yield of the cane plants and ratoon crops (ELAWAD; GASCHO; STREET, 1982). Similarly, Ayres (1966) showed an $18 \%$ increase in yield and a $22 \%$ increase in sugar production with the use of $6.2 \mathrm{Mg} \mathrm{ha}^{-1}$ slag applied in oxisol, in Hawaii (USA).

Cane plant and ratoon crops seem to respond differently to $\mathrm{Si}$ application The slag residual effect was more significant in increasing the production of ratoons than the production of cane plant (PRADO; FERNANDES, 2001b). This result could be due to the attenuated decay of production throughout the culture cuts. These results are in accordance with those of Anderson, Snyder and Martin (1991), who found, average reductions of $45 \%$ and $28 \%$ in stalk yield of ratoons in plots during the first three cycles with and without the application of slag, respectively.

The dose of slag for soil acidity correction in sugarcane areas should be in accordance with the base saturation method, with the aim of raising the value to $80 \%$, which should have enough residual effect for the entire crop cycle. Although there is still no standard dose recommendation based on calibration 
studies of available $\mathrm{Si}$ in soil and yield of sugarcane, the available data indicate that doses should range from 3 to $6 \mathrm{t}$ of silicate per hectare (PRADO; FERNANDES; NATALE, 2001).

\section{Concluding Remarks}

In an intensive cultivation system aiming high productivity, a proper fertilization is fundamental and, in this sense, the silicates can provides nutrients, act as a soil acidity neutralizer and increase the plant tolerance against biotic and abiotic stresses.

\section{References}

ALCARDE, J.C. Corretivos da acidez dos solos: características e interpretações técnicas. São Paulo: ANDA, 1992. 24 p. (Boletim Técnico, n. 6).

ANDERSON, D. L.; SNYDER, G. H.; MARTIN, F. G. Multi-year response of sugarcane to calcium silicate slag on everglades histosols. Agronomy Journal, v. 83, p. 870-874, 1991.

ANDERSON, D. L.; BOWEN, J. E. Nutrição da cana-de-açúcar. Piracicaba: Potafós, 1992. 40 p.

ARRUDA, D. P. Avaliação de extratores químicos na determinação de silício disponível em solos cultivados com cana-de-açúcar. $2009.78 \mathrm{f}$. (Dissertação: Mestrado em Agronomia)-Faculdade de Ciências Agronômicas, Universidade Estadual Paulista, Botucatu, 2009.

ASHRAF, M.; RASHID, M. H.; KHAN, Z. I.; HUSSAIN, A.; GHAFOOR, M. Y.; PARVEEN, R. Sugarcane, sugar metabolism and some abiotic stresses. Journal of Agricultural Biology, v. 6, p. 732-742, 2004.

AYRES, A. S. Calcium silicate slag as a growth stimulant for sugarcane on low-silicon soils. Soil Science, v. 101, n. 3, p. 216-227, 1966.

BAUER, P.; ELBAUM, R.; WEISS, I. M. Calcium and silicon mineralization in land plants: Transport, structure and function. Plant Science, v. 180, p. 746-756, 2011. http://dx.doi.org/10.1016/j. plantsci.2011.01.019

BÉLANGER, R. R.; BOWEN, P. A.; EHRET, D. L.; MENZIES, J. G. Soluble silicon: its roles in crop and disease management of greenhouse crops. Plant Disease, v. 79, p. 329-336, 1995. http:// dx.doi.org/10.1094/PD-79-0329

BRASIL. Ministério da Agricultura, Pecuária e Abastecimento - MAPA. Legislação. Disponível em: <http://www.agricultura.gov.br/vegetal/ fertilizantes/legislacao>. Acesso em: 09 maio 2012.

CAMARGO, M. S.; KORNDÖRFER, G. H.; FOLTRAN, D. E.; HENRIQUE, C. M.; ROSSETTO, R. Absorção de silício, produtividade e incidência de Diatraea saccharalis em cultivares de cana-de-açúcar. Bragantia, v. 69, n. 4, p. 937-944, 2010. http:// dx.doi.org/10.1590/S0006-87052010000400020

COCKER, K. M.; EVANS, D. E.; HODSON, M. J. The amelioration of aluminum toxicity by silicon in higher plants: solution chemistry or an in plants mechanisms? Physiologia Plantarum, v. 104, p. 608-614, 1998. http://dx.doi.org/10.1034/j.1399-3054.1998.1040413.x

DATNOFF, L. E.; RODRIGUES, F. A.; SEEBOLD, K. W. Silicon and plant disease. In: DATNOFF, L. E.; ELMER, W. H.; HUBER,
D. M. Mineral nutrition and plant disease. St. Paul: The American Phytopathological Society Press, 2007. p. 233-246.

DATNOFF, L. E.; SNYDER, G. H.; KORNDÖRFER, G. H. Silicon in Agriculture. Amsterdam: Elsevier, 2001. 403 p.

DAYANANDAM, P.; KAUFMAN, P. B.; FRAKIN, C. I. Detection of silica in plants. American Journal of Botany, v. 70, p. 1079-1084, 1983.

DEMATTÊ, J. L. I.; PAGGiARO, C. M.; BELTRAME, J. A.; RIBEIRO, S. S. Uso de silicatos em cana-de-açúcar. Informações Agronômicas, n. 133, p. 7-12, 2011.

DEREN, C. W.; GLAZ, B.; SNYDER, G. H. Leaf-tissue silicon content of sugarcane genotypes grown on Everglades Histosols. Journal of Plant Nutrition, v. 16, n. 11, p. 2273-2280, 1993. http:// dx.doi.org/10.1080/01904169309364685

ELAWAD, S. H.; GASCHO, G. J; STREET, J. J. Response of sugarcane to silicate source and rate. II. Leaf freckling and nutrient content. Agronomy Journal, v. 74, p. 484-87, 1982.

EPSTEIN, E. Silicon. Annual Review of Plant Physiology and Plant Molecular Biology, v. 50, p. 641-664, 1999.

EPSTEIN, E. Silicon: its manifold roles in plants. Annals of Applied Biology, v. 155, p. 155-160, 2009. http://dx.doi.org/10.1111/j.17447348.2009.00343.x

EXLEY, C. Silicon in life: A bioinorganic solution to bioorganic essentiality. Journal of Inorganic Biochemistry, v. 69, p. 139-144, 1998.

FAWE, A.; MENZIES, J. G.; CHÉRIF, M.; BÉLANGER, R. R. Silicon and disease resistance in dicotyledons. In: DATNOFF, L. E.; SNYDER, G. H.; KORNDÖRFER, G. H. Silicon in agriculture. New York: Elsevier Science, 2001. p. 159-169.

FOY, C. D. Soil chemical factors limiting plant root growth. Advances in Soil Science, v. 19, p. 97-149, 1992. http://dx.doi.org/10.1007/9781-4612-2894-3_5

GAO, X. P.; ZOU, C. Q.; WANG, L. J.; ZHANG, F. Z. Silicon improves water use efficiency in maize plants. Journal of Plant Nutrition, v. 27, n. 8, p. 1457-1470, 2004. http://dx.doi.org/10.1081/ PLN-200025865

GOMES, F. B.; MORAES, J. C.; SANTOS, C. D.; ANTUNES, C. S. Uso de silício como indutor de resistência em batata a Myzus persicae (Sulzer) (Hemiptera: Aphididae). Neotropical Entomology, v. 37, p. 185-190, 2008. http://dx.doi.org/10.1590/ S1519-566X2008000200013

KEEPING, M. G.; KVEDARAS, O. L.; BRUTON, A. G. Epidermal silicon in sugarcane: Cultivar differences and role in resistance to sugarcane borer Eldana saccharina. Environmental and Experimental Botany, v. 66, p. 54-60, 2009. http://dx.doi.org/10.1016/j. envexpbot.2008.12.012

KEEPING, M. G.; MEYER, J. H. Calcium silicate enhances resistance of sugarcane to the African stalk borer Eldana saccharina Walker (Lepidoptera: Pyralidae). Agricultural and Forest Entomology, v. 4, p. 265-274, 2002. http://dx.doi.org/10.1046/j.14619563.2002.00150.x

KORNDÖRFER, A. P.; GRISOTO, E.; VENDRAMIM, J. D. Induction of insect plant resistance to the spittlebug Mahanarva fimbriolata Stål (Hemiptera: Cercopidae) in sugarcane by silicon 
application. Neotropical Entomology, v. 40, n. 3, p. 387-392, 2011. http://dx.doi.org/10.1590/S1519-566X2011000300013

KORNDÖRFER, G. H.; PEREIRA, H. S.; CAMARGO, M. S. Silicatos de cálcio e magnésio na agricultura. 3. ed. Uberlândia: GPSi/ICIAG/UFU, 2004. 24 p. (Boletim Técnico, n. 1).

KORNDÖRFER, G. H.; PEREIRA. H. S.; NOLLA. A. Análise de silício: solo, planta e fertilizante. Uberlândia: GPSi/ICIAG/ UFU, 2004. 34 p. (Boletim Técnico, n. 2).

KORNDÖRFER, G. H.; PEREIRA, H. S.; CAMARGO, M. S. Papel do silício na produção de cana-de-açúcar. Revista $S T A B$, v. 21, n. 1, p. 6-9, 2002.

KORNDÖRFER, G. H.; DATNOFF, L. E. Adubação com silício: uma alternativa no controle de doenças de cana-de-açúcar e arroz. Informações Agronômicas, n. 70, 1995.

KVEDARAS, O. L.; KEEPING, M. G.; GOEBEL, F-R.; BYRNE, M. J. Larval performance of the pyralid borer Eldana saccharina Walker and stalk damage in sugarcane: influence of plant silicon, cultivar and feeding site. International Journal of Pest Management, v. 53, p. 183-194, 2007. http://dx.doi.org/10.1080/09670870601110956

LIANG, Y. C.; SUN, W.; ZHU, Y. G.; CHRISTIE, P. Mechanisms of silicon-mediated alleviation of abiotic stresses in higher plants: a review. Environmental pollution, v. 147, p. 422-428, 2007. http:// dx.doi.org/10.1016/j.envpol.2006.06.008

LIMA FILHO, O. F.; LIMA, M. T. G.; TSAI, S. M. O silício na agricultura. Informações Agronômicas, n. 87, p. 1-7, 1999.

LUX, A.; LUXOVA, M.; HATTORI, T.; ININAGA, S.; SUGIMOTO, Y. Silicification in sorghum (Sorghum bicolor) cultivars with diferent drought tolerance. Physiologia Plantarum, v. 115, p. 87-92, 2002. http://dx.doi.org/10.1034/j.1399-3054.2002.1150110.x

MA, J. F.; YAMAJI, N. Functions and transport of silicon in plants. Cellular and Molecular Life Sciences, v. 65, p. 3049-3057, 2008. http://dx.doi.org/10.1007/s00018-008-7580-x

MA, J. F.; TAMAI, K.; YAMAJI, N.; MITANI, N.; LKONISHI, S.; KATSUHARA, M.; ISHIGURO, M.; MURATA, Y.; YANO, M. A silicon transporter in rice. Nature, v. 440, p. 688-691, 2006. http:// dx.doi.org/10.1038/nature04590

MA, J. F. Role of silicon in enhancing the resistance of plants to biotic and abiotic stresses. Soil Science and Plant Nutrition, v. 50, p. 11-18, 2004.

MA, J. F.; TAKAHASHI, E. Soil, fertilizer and plant silicon research in Japan. New York: Elsevier Science, 2002. 274 p.

MA, J. F.; MIYAKE, Y.; TAKAHASHI, E. Silicon as a beneficial element for crop plant. In: DATNOFF, L. E.; KORNDÖRFER, G. H.; SNYDER, G. Silicon in Agriculture. New York: Elsevier Science. 2001. p. 17-39.

MADEIROS, L. B.; VIEIRA, A. O.; AQUINO, B. Micronutrientes e silício nas folhas da cana-de-açúcar: escória siderúrgica aplicada no solo. Engenharia Ambiental, v. 6, p. 27-37, 2009.

MAKSIMOVIC, J. D.; BOGDANOVIC, J.; MAKSIMOVIC, V.; NIKOLIC, M. Silicon modulates the metabolism and utilization of phenolic compounds in cucumber (Cucumis sativus L. ) grown at excess manganese. Journal of Plant Nutrition and Soil Science, v. 170, p. 739-744. 2007. http://dx.doi.org/10.1002/jpln.200700101
MALAVOLTA, E.; PIMENTEL-GOMES, F.; ALCARDE, J. C. Adubos e adubações: adubos minerais e orgânicos, interpretação da análise do solo, prática da adubação. São Paulo: Nobel, 2002. 220 p.

MARSCHNER, H. Mineral nutrition in higher plant. London: Academic Press, 1995. 889 p.

MATICHENKOV, V. V.; CALVERT, D. V. Silicon as a beneficial element for sugarcane. Journal of the American Society of Sugarcane Technologists, v. 22, p. 21-30, 2002.

MITANI, N.; CHIBA, Y.; YAMAJI, N.; MA, J. F. Identification and characterization of maize and barley lsi2-like silicon efflux transporters reveals a distinct silicon uptake system from that in rice. Plant Cell, v. 21, p. 2133-2142, 2009. http://dx.doi.org/10.1105/ tpc.109

MITANI, N.; MA, J. F. Uptake system of silicon in different plant species. Journal of Experimental Botany, v. 56, p. 1255-1261, 2005. http://dx.doi.org/10.1093/jxb/eri121

NAIDOO, P. V.; MCFARLANE, S. A.; KEEPING, M. G.; CALDWELL, P. M. Deposition of silicon in leaves of sugarcane (Saccharum spp. hybrids) and its effect on the severity of brown rust caused by Puccinia melanocephala. Proceedings of South African Sugar Technology Association, v. 82, p. 542-546, 2009.

NOLLA, A.; FARIA, R. J.; KORNDÖRFER, G. H.; SILVA, T. R. B. Effect of silicon on drought tolerance of upland rice. Journal of Food, Agriculture and Environment, v. 10, n. 1, 2012.

ORLANDO FILHO, J.; MACEDO, N.; TOKESHI, H. Seja o doutor do seu canavial. Informações Agronômicas, n. 76 (Encarte Técnico), 1994.

PRADO, R. M. Resposta da cana-de-açúcar à aplicação de escória silicatada como corretivo de acidez do solo. 2000. Dissertação (Mestrado em Agronomia)-Faculdade de Engenharia, Universidade Estadual Paulista, Ilha Solteira, 2000.

PRADO, R. M.; FERNANDES, F. M. Eficiência da escória de siderurgia em areia quartzosa na nutrição e na produção de matéria seca de cana-de-açúcar cultivada em vaso. Revista $S T A B$, v. 18, p. 36-39, 2000.

PRADO, R. M.; FERNANDES, F. M. Resposta da cultura da canade-açúcar à aplicação de escória de siderurgia como corretivo de acidez do solo. Revista Brasileira de Ciência do Solo, v. 25, p. $201-$ 209, 2001a.

PRADO, R. M.; FERNANDES, F. M. Efeito da escória de siderurgia e do calcário na disponibilidade de fósforo em um Latossolo VermelhoAmarelo cultivado com cana-de-açúcar. Pesquisa Agropecuária Brasileira, v. 36, n. 9, p. 1199-1204, 2001b. http://dx.doi.org/10.1590/ S0100-204X2001000900014

PRADO, R. M.; FERNANDES, F. M.; NATALE, W. Uso agrícola da escória de siderurgia no Brasil: estudos na cultura da cana-de-açúcar. Jaboticabal: FUNEP, 2001. 67 p.

PRADO, F. M.; FERNANDES, F. M.; NATALE, W. Efeito residual da escória de siderurgia como corretivo de acidez do solo na soqueira de cana-de-açúcar. Revista Brasileira de Ciência do Solo, v. 27, p. 287-296, 2003.

RAFI, M. M.; EPSTEIN, E.; FALK, R. H. Silicon deprivation causes physical abnormalities in wheat (Triticum aestivum L. ). Journal of 
Plant Physiology, v. 151, p. 497-501, 1997. http://dx.doi.org/10.1016/ S0176-1617(97)80017-X

RAID, R. N.; ANDERSON, D. L.; ULLOA, M. F. Influence of cultivar and amendment of soil with calcium silicate slag on foliar disease development and yield of sugar cane. Crop Protection, v. 11, p. 84-88, 1992. http://dx.doi.org/10.1016/0261-2194(92)90085-J

REYNOLDS, O. L.; KEEPING, M. G.; MEYER, J. H. Siliconaugmented resistance of plants to herbivorous insects: a review. Annals of Applied Biology, v. 155, p. 171-186, 2009. http://dx.doi. org/10.1111/j.1744-7348.2009.00348.x

RODRIGUES, F. A.; BENHAMOU, N.; DATNOFF, L. E.; JONES, J. B.; BÉLANGER, R. R. Ultrastructural and cytochemical aspects of silicon-mediated rice blast resistance. Phytopathology, v. 93, p. 535-546, 2003. http://dx.doi.org/10.1094/PHYTO.2003.93.5.535

RODRIGUES, F. A.; OLIVEIRA, L. A.; KORNDÖRFER, A. P.; KORNDÖRFER, G. H. Silício: elemento benéfico e importante às plantas. Informações Agronômicas, n. 134, p. 14-20, 2011.

ROGALLA, H.; ROMHELD, V. Role of leaf apoplast in siliconmediated manganese tolerance of Cucumuis sativus L. Plant Cell and Environment, v. 25, p. 549-555, 2002.
SAVANT, N. K.; KORNDÖRFER, G. H.; DATNOFF, L. E.; SNYDER, G. H. Silicon nutrition and sugarcane production: a review. Journal of Plant Nutrition, v. 22, n. 12, p. 1853-1903, 1999. http:// dx.doi.org/10.1080/01904169909365761

SHI, Q. H.; BAO, Z. Y.; ZHU, Z. J.; HE, Y.; QIAN, Q. Q.; YU, J. Q. Silicon-mediated alleviation of Mn toxicity in Cucumis sativus in relation to activities of superoxide dismutase and ascorbate peroxidase. Phytochemistry, v. 66, p. 1551-1559, 2005.

SOUSA, R. T. X.; KORNDÖRFER, G. H.; WANGEN, D. R. B. Aproveitamento de silício proveniente de escória siderúrgica por cultivares de cana-de-açúcar. Bragantia, v. 69, n. 3, p. 669-676, 2010. http://dx.doi.org/10.1590/S0006-87052010000300019

TISDALE, S. L.; NELSON, W. J.; BEATON, J. D. Soil Fertility and Fertilizers. New York: Macmilan Publishing Company, 1993. 634p.

YOSHIDA, S.; OHNISHI, Y.; KITAGISHI, K. Chemical forms mobility and deposition of silicon in rice plant. Soil Science and Plant Nutrition, v. 8, p. 15-21, 1962. http://dx.doi.org/10.1080/003 80768.1962.10430992

ZUCCARINI, P. Effects of silicon on photosynthesis, water relations and nutrient uptake of Phaseolus vulgaris under $\mathrm{NaCl}$ stress. Biologia Plantarum, v. 52, n. 1, p. 157-160, 2008. http://dx.doi.org/10.1007/ s10535-008-0034-3 